\title{
Gen Y Consumers' Brand Loyalty: A Brand Romance Perspective
}

\author{
Dilan Tharindu Rathnayake \\ Department of Marketing Management, University of Sri Jayewardenepura, \\ Nugegoda, Sri Lanka and \\ Department of Marketing, University of Strathclyde, Glasgow, UK
}

This article is published in Marketing Intelligence and Planning. The link to the published version in the journal is: https://www.emerald.com/insight/content/doi/10.1108/MIP-09$\underline{2020-0421 / \text { full/html }}$

DOI 10.1108/MIP-09-2020-0421

This Author Accepted Manuscript is published under the licence CC BY-NC 4.0. Emerald is the publisher of this article and permission has been granted for this version to appear here (https://pureportal.strath.ac.uk). Emerald does not grant permission for this article to be further copied/distributed or hosted elsewhere without their express permission. To reuse the AAM for commercial purposes, permission should be sought by contacting permissions@emeraldinsight.com. 


\title{
Gen Y Consumers' Brand Loyalty: A Brand Romance Perspective
}

\begin{abstract}
Purpose - As Generation Y is considered to be a lucrative segment for emerging devices, this study investigates the effect of emotional brand attachment, from the brand romance perspective, on brand loyalty of Generation Y smartphone users. Further, this study examines gender differences in the same relationship.

Design/methodology/approach - The study adopted a cross-sectional survey method and data was collected from 300 respondents. Data was analysed using the structural equation modelling (SEM) approach and multi-group analysis was performed to examine gender differences in the model.

Findings - Results revealed that all three aspects of brand romance (pleasure, arousal, and dominance) have a positive impact on smartphone brand loyalty. It further denotes that the relationship between brand romance and brand loyalty differs from males to females.

Originality - This study makes a significant contribution by examining emotional attachment and brand loyalty of Generation Y consumers, which has been less investigated. Further, both attitudinal and behavioral brand loyalty has been considered in this study, which has largely been overlooked in similar studies. Examining the gender difference in the above relationship is an additional contribution.
\end{abstract}

Keywords: Emotional Brand Attachment, Brand Romance, Pleasure, Arousal, Dominance, Attitudinal Loyalty, Behavioural Loyalty, Generation Y 


\section{Introduction}

Smartphones have become a vital aspect of individuals' everyday lives. The global smartphone industry has grown exponentially, which appears to continue further (Mukherjee, 2019). The number of worldwide smartphone users was 2.9 billion in 2018 which is expected to reach 3.5 billion by 2020, with an annual sale of 1.56 billion smartphones to end-users (Statista, 2020). This tremendous growth is backed by the introduction of new operating systems and diversification of applications (Martins et al., 2019) which attract novelty-seeking consumers. Consequently, smartphones have severely affected the way people communicate with each other and become a necessity of personal as well as professional lives (Derks et al., 2016). This enormous growth of the smartphone industry has, therefore, attracted much scholarly attention (Yeh et al., 2016; Martins et al., 2019).

It is further evident that, consumers are more loyal to a few smartphone brands despite the availability of many brands in the market. At present, the global mobile market is dominated by three brands: Samsung, Apple, and Huawei accounting for $67 \%$ of the total market share (Statcounter, 2020) symbolizing the consumer dependency on brands. This is more intensified in Sri Lanka, where Samsung, Huawei, and Apple hold market shares 42.63\%, 24.65\%, and 9.95\% respectively (Statcounter, 2020). Within this context, ensuring customer loyalty has become a major concern and smartphone manufacturers are in a continuous effort to increase customer satisfaction, thereby, achieve customer loyalty (Chen et al., 2016). This effort is supported by strategies such as offering new versions, features and software upgrades (Chen et al., 2016; Hung et al., 2018). Concerning this, Kim et al. (2016) and Kim et al. (2020) emphasized the significance of understanding the predictors of customer loyalty in the smartphone industry.

In extant literature, numerous predictors of brand loyalty have been investigated. However, consumers' emotional attachment to brands (Round and Roper, 2012) which fosters a long term brand-consumer relationship (Long-Tolbert and Gammoh, 2012) still appears to be an interesting research avenue. As emphasized by Phau et al. (2013), the emotional attachment is a key to cultivate strong customer-brand relationships and, it has been examined as a predictor of brand loyalty in various contexts including automobile (Loureiro et al., 2017), banking (Khan and Rahman, 2017), and fashion (U1 Hassan et al., 2016). However, such studies about the smartphone industry are scarce. Therefore, this study primarily aims to investigate the effect of emotional brand attachment on brand loyalty in the Sri Lankan smartphone industry. In 
doing so, this study takes the Brand Romance perspective (Patwardhan and Balasubramanian, 2011) to comprehensively capture the emotional brand attachment. Further, many studies in this domain have considered brand loyalty as a unidimensional construct, however, this study takes both attitudinal and behavioral loyalty into account. Additionally, following the argument that individual heterogeneity should be considered in examining brand loyalty (Floh et al., 2014; Yeh et al., 2016), this study aims to investigate gender differences in the aforesaid relationship. In summing up, the objectives of this paper are:

1. To investigate the effect of emotional brand attachment (brand romance) on smartphone brand loyalty.

2. To investigate if the relationship between emotional brand attachment and smartphone brand loyalty differs in terms of gender.

In achieving these objectives, this study specifically selected Generation Y (Gen Y) consumers considering their heavy usage of emerging devices (Lazarevic, 2012; Smith, 2015; Giovanis and Athanasopoulou, 2017). As noted by Prasad et al. (2019), Gen Y is largely distinguished from other generational cohorts due to the intense exposure to the latest technologies. It is a market segment with a greater spending power and a high growth potential (Giovanis and Athanasopoulou, 2017). Further, Gen Y consumers are less likely to respond well to advertising (Kim and Hahn, 2012) and their brand loyalty tendencies are unclear (Lazarevic, 2012). Yet, this segment is innovative and keen to purchase fashionable brands (Dawn and Thomas, 2013). Therefore, examining predictors of smartphone brand loyalty in the Gen Y segment seems to be scholarly sensible, and practically important.

\section{Literature review}

\subsection{Brand loyalty}

Extant literature provides various definitions to the brand loyalty. According to Ballantyne et al. (2006), brand loyalty is a favorable attitude and a commitment towards a brand, leading to continuous purchase. Oliver (1999) defined brand loyalty as "a deeply held commitment to rebuy or repatronize a preferred product/service consistently in the future, thereby causing repetitive same-brand or same brand-set purchasing, despite situational influences and marketing efforts having the potential to cause switching behavior" (p.34). This comprehensive definition vividly illustrates the two aspects of brand loyalty: attitudinal and behavioral loyalty, that have been even depicted in other scholarly works (e.g., Wood, 2000; Aaker, 2009; Yeh et al. 2016). Due to its significance, firms have been thoroughly considerate about customer 
loyalty as a key success factor in the market (Tsimonis and Dimitriadis, 2014). Confirming this, Prasad et al. (2019), noted that highly loyal customers would virtually exclude competitive products/brands/firms from their consideration.

The definitions and measurements of brand loyalty have emerged from two schools of thought (Bandyopadhyay and Martell, 2007) representing attitudinal and behavioral aspects. In early scholastic works, brand loyalty was defined strictly from the behavioral facet (e.g., Kahn et al., 1986; Ehrenberg et al., 1990) denoting that repeat purchase represents a consumer's loyalty. In this regard, previous researchers have observed the proportion (e.g., Blattberg and Sen, 1974) and the sequence of brand purchases (Kahn et al., 1986). However, later studies signified the attitudinal aspect of brand loyalty. According to Dick and Basu (1994), favorable attitudes must be incorporated in measuring brand loyalty, in addition to repeat purchases. The premise behind attitudinal loyalty is that a favorable attitude towards a brand would guarantee a repeat purchase (Bandyopadhyay and Martell, 2007). Moreover, Chaudhuri and Holbrook (2001), Yeh et al. (2016), and Giovanis and Athanasopoulou (2017) revealed that both attitudinal and behavioral loyalty significantly contribute to the performance of a brand.

\subsection{Emotional brand attachment}

In early periods, the attitude was considered to be the predictor of brand commitment (loyalty). However, researchers later suggested that attitude alone is insufficient to predict brand loyalty and customers should form an emotional connection with the brand to be truly loyal (Park et al., 2009). Tangsupwattana and Liu (2018), for example, signified the vital role of emotional experience in symbolic consumption, which leads to brand loyalty. Similarly, Giovanis and Athanasopoulou (2017) and Toufani et al. (2017) highlighted that the emotional value of a brand plays a vital role in forming brand loyalty intentions.

The fundamental insight of emotional brand attachment was borrowed from the Attachment Theory (Bowlby, 1979) which concerns interpersonal relations. Later studies found that individuals can be emotionally attached to various objects such as gifts, and brands (Phau et al., 2013; Park et al., 2010). Following this, Esch et al. (2006) defined emotional brand attachment as an enduring commitment provoking the bond between consumer and a brand. Further, the emotional attachment between a brand and consumer largely depends on trust, dependability, and consistency of response (Patwardhan and Balasubramanian, 2011). Consequently, an emotional attachment can strengthen favorable feelings about the brand and lead to more customer retention/loyalty (Loureiro et al., 2012; Loureiro et al., 2017). 
Prior scholarly works have found that brand attachment is a significant predictor of brand loyalty. However, a critical view of such studies unfolds ample opportunities where future studies can significantly contribute to the knowledge in this domain. For instance, numerous recent works have neglected the multi-faceted nature of emotional brand attachment. BahriAmmari et al. (2016), Frasquet et al. (2017), Kumar and Nayak (2019), and Levy and Hino (2016) found brand attachment to be a predictor of brand loyalty, however, they considered brand attachment as a uni-dimensional construct. Though some other investigations (e.g., Boateng et al., 2020) attempted to capture the multi-faceted nature of attachment, they have not specifically focused on 'emotional brand attachment'. Accordingly, it is imperative to investigate emotional brand attachment with a much comprehensive, multi-faceted view. Similarly, the multi-faceted nature of brand loyalty has also been overlooked in previous studies (e.g., Boateng et al., 2020; Levy and Hino, 2016; Giovanis and Athanasopoulou, 2017).

Though emotional brand attachment and brand loyalty have been investigated in various contexts such as automobile (Loureiro et al., 2012) and fashion industry (Phau et al., 2013; Thakur and Kaur, 2016), less empirical studies have concerned Gen Y and the smartphone industry despite their significance. Concerning Gen Y, recent studies have investigated various consumption behaviors including emotional experience and symbolic consumption (Tangsupwattana and Liu, 2018), brand loyalty drivers in emerging devices (Giovanis and Athanasopoulou, 2017), and purchase decisions in the online environment (Prasad et al., 2019). Yet, no studies have focused on emotional attachment (specifically brand romance) and brand loyalty.

\subsubsection{Brand romance}

Among numerous approaches that attempted to conceptualize and measure emotional brand attachment, Brand Romance (Patwardhan and Balasubramanian, 2011) emerged as a fashionable and comprehensive model. It has borrowed roots from the self-expansion model (Aron et al., 1998) which elaborates the expansion of one's self by acquiring perspectives, resources, and identities. During this process, one can access the partner's self (e.g., partner's perspectives, resources, and identities) which might lead to romantic involvements. Later, this analogy was extended to consumer-brand relationships (Reimann and Aron, 2009) proposing that brands have their own perspectives, resources, and identities. Patwardhan and Balasubramanian (2011), for example, illustrated that Blackberry phone users recognize 
themselves with brand's perspectives and embrace attitudes and behaviors of the brand, thus, being proud to carry the brand with them.

However, the self-expansion model did not consider what happens when such a consumerbrand relationship matures. Considering this, Patwardhan and Balasubramanian (2011) proposed the concept 'Brand Romance' which was defined as "a state of emotional attachment (evoked in response to the brand as a stimulus) that is characterized by strong positive affect toward the brand, high arousal caused by the brand, and a tendency of the brand to dominate the consumer's cognition" (p.299). This definition demarcates three aspects of emotional attachment: a strongly favorable effect on the stimulus (brand), greater arousal caused by the brand, and the domination of the brand in consumer's cognition. These aspects were named as: Pleasure, Arousal, and Dominance.

\section{Pleasure}

Patwardhan and Balasubramanian (2011) defined pleasure as the "extent that the stimulus brand imparts pleasure to the consumer" (p.299). Pleasure is a hedonic quality of a stimulus (i.e., brand) (Feldman, 1995) and is in the category of emotions which includes love, desire, attraction, and fun. According to Shimp (1988), an object that pleases a person would be the foremost element to inculcate a desire for a romantic relationship. Previous studies found a positive association between pleasure and brand loyalty. For example, Hanzaee et al. (2011) reported that pleasure has a direct positive effect on brand loyalty. Similarly, Quester and Lim (2003) reported interest and pleasure as strong (positive) predictors of brand loyalty. Thus, it can be argued that if the brand pleases the consumer, there would be a high probability to achieve brand loyalty. Accordingly, the following hypothesis is posited:

Hla; Pleasure has a positive impact on attitudinal brand loyalty of Gen Y smartphone users.

H1b; Pleasure has a positive impact on behavioral brand loyalty of Gen Y smartphone users.

\section{Arousal}

Though the consumer-brand relationship evokes positive feelings, it would not be meaningful or effective unless such feelings are intense enough to arouse the consumer (Patwardhan and Balasubramanian, 2011). Even, the self-expansion model elucidates that expression in shopping experiences may be characterized by strong arousal tendencies (Aron et al., 1998). Mehrabian and Russell (1974) recognized arousal as a subjective emotional state, and Mehrabian (1996) defined arousal as a blend of both mental vigilance and physical activity. At 
the high end, arousal has been identified with connotations such as "wakefulness, bodily tension, strenuous exercise, and concentration at the high end" (Bakker et al., 2014, p.5). Prior works revealed that arousal significantly affects brand loyalty. For example, Han et al. (2018) found that arousal has a positive impact on brand satisfaction which leads to brand loyalty in the coffee shop industry. Similarly, arousal has been a strong predictor of brand loyalty in the cell phone industry (Petzer et al., 2014) and the motorbike industry (Ali et al., 2017). Accordingly, this study hypothesizes:

H2a; Arousal has a positive impact on attitudinal brand loyalty of Gen Y smartphone users.

H2b; Arousal has a positive impact on the behavioral brand loyalty of Gen Y smartphone users.

\section{Dominance}

Dominance represents the brand's propensity to engage the cognition of customers (Patwardhan and Balasubramanian, 2011). This is a depiction of the consumer's cognitive process and the power of a brand in dominating the customer's mind. In this emotional state, the brand becomes a vital aspect of the consumer's life and the brand may "[...] become inextricably embedded within some portion of the consumer's psyche, as well as his/her lifestyle" (Oliver, 1999, p.40). Due to this cognitive dominance, the individual would claim the brand to be a "part of me" and an "extension of me" (see Belk, 1988). As noted by Ali et al. (2017), dominance may occupy a larger proportion of the consumer's mind for a brand. Dominance can sometimes be negative, however, it might provoke repurchasing and brand loyalty when it does not limit the consumers' freedom (Mehrabian and Russell, 1974). Prior works such as Hatice and Cemal (2017) found that dominance has a positive impact on brand loyalty of young consumers. The same findings were reported by other studies such as Petzer et al. (2014) and Ali et al. (2017). Therefore, this study hypothesizes:

H3a; Dominance has a positive impact on attitudinal brand loyalty of Gen Y smartphone users. H3b; Dominance has a positive impact on behavioral brand loyalty of Gen Y smartphone users.

\subsubsection{Effect of gender}

Both practitioners and scholars have long considered individual heterogeneity in market relationships. Highlighting this, Floh et al. (2014) signified the need to consider individual heterogeneity in examining loyalty intentions. Among individual variables, gender proved to produce distinctive attitudes and behaviors. Yeh et al. (2016), for instance, emphasized that 
males are more independent while females are dependent and relationship-oriented. To this end, it can be argued that emotional brand attachment and loyalty may vary across gender.

Though investigations on gender differences in brand romance and brand loyalty are scarce, scholarly works from other disciplines provide useful directions for an argument. Sun et al. (2010), for example, claimed that females are predominantly behaving from an emotional view and are driven by expressions such as enjoyment. This notion confirms the view of McCarty and Kaye (1984) who argued that enjoyment is a prime motivation for women. Kuss and Griffiths (2011) also revealed that intrinsic reinforcement of entertainment is central to the behavior of women during IT usage, thereby, women concern more about their emotions. Following this, Chen et al. (2017) argued and found that females are more driven by enjoyment when using smartphones. Based on the view that enjoyment and entertainment reflect pleasure, it would be rational to argue that women seek more pleasure from smartphone brands and tend to be loyal to brands that impart pleasure. Accordingly, this study hypothesizes:

H4a; The effect of pleasure on smartphone brand loyalty is higher among Gen Y females than males.

Numerous studies exemplify that men are less likely to be aroused by smartphones than women. Takao et al. (2009) found that women are heavy users of mobile phones, even under situations where mobile phone usage is regulated (i.e., driving). Such an excessive usage can be an indication of arousal triggered by positive feelings about a product. Qi et al. (2015), extending the same notion to mobile data services, found that female customers are more likely to continue the attachment with brands. As argued by Hew et al. (2017), females maintain a continuous intention to buy smartphones as a demonstration of high perceived usefulness and satisfaction resulted from usage of smartphone brands. The same argument can be extended to claim that continuous purchase intention caused by positive feelings (i.e., satisfaction) is an indication of arousal (i.e., excitement). Accordingly, this study assumes that Gen Y females are more aroused by smartphone brands and hypothesizes that:

H4b; The effect of arousal on smartphone brand loyalty is higher among Gen Y females than males.

Extant literature on addictive behavior exemplify the dominance of smartphones in male's cognition than females. van Deursen et al. (2015), for instance, argued that males show more addictive smartphone behaviors than females. Aljomaa et al. (2016) confirmed the same notion by unfolding that males are frequent users of smartphones than women. Bridging this addictive 
and attachment behaviors, prior studies have found that addiction in the context of technology leads to attachment behavior (Lee et al., 2013). Accordingly, Hew et al. (2017) implied that men have a strong attachment to smartphone brands leading to continuous purchase intention. Therefore, it can be assumed that addictive behavior followed by attachment and purchase intention is a strong indication of the smartphone brand dominance in men's cognition that leads to brand loyalty. Hence, it is hypothesized that:

H4c; The effect of dominance on smartphone brand loyalty is higher among Gen Y males than females.

\section{Methods}

\subsection{Measures}

A structured questionnaire, consisting of three sections, was used to collect data. The first section covered general information (the smartphone brand used by the respondent and the number of mobile connections used). The second section measured constructs: pleasure, arousal, dominance, and brand loyalty whereas the third section covered demographic information. Validated scales developed in previous studies were used to measure constructs (see appendix). Specifically, the measures of brand romance were adapted from Patwardhan and Balasubramanian (2011) and the measures of brand loyalty were adapted from Gecti and Zengin (2013). Respondents were asked to state their level of agreement with each statement using five-point Likert scale ( 1 = Strongly Disagree, 5 = Strongly Agree).

Following procedural remedies proposed by Podsakoff et al. (2011) were applied to avoid potential common method bias: (1) making items unambiguous and easy to understand, (2) avoiding wordings that lead to social desirability in answering, and (3) presenting a few reversed items in the final questionnaire. Sections of the questionnaire were separated and instructions to respondents were given at the beginning of each section to distract the monotonousness. The questionnaire was pre-tested before the final data collection. Confidentiality of responses was ensured, and the researcher personally explained the purpose of the data collection to respondents, avoiding non-response bias.

\subsection{Data collection and demographic profile}

The overall research design of this study was cross-sectional (survey). Unit of analysis was individual Gen Y smartphone users (born between 1980 and 1994) (Lazarevic, 2012) in Sri Lanka and respondents were selected purposively. The survey was conducted using both 
personal and online methods during the second quarter of 2019. In the personal method, the researcher personally presented the questionnaire to respondents at four premises: two universities and two shopping malls. Most of these respondents were from the western province. 170 questionnaires were presented, and the response rate was $92 \%$. During the online survey, the researcher sent the online version of the questionnaire (a google form) to qualified respondents via email and social network platforms. Ensuring the sample representativeness, the online questionnaire was mostly sent to respondents from areas other than the western province. 230 online questionnaires were sent, and the response rate was $70 \%$. Accordingly, a total of 316 completed questionnaires were received and, after scrutinizing for completeness and appropriateness, 300 responses were forwarded to the validation and analysis. Further, an independent samples t-test was performed to assess if there is a difference between data collected using online and personal methods. Results of the test (pleasure: $t=0.307, p=0.759$; arousal: $t=-0.160, p=0.873$; dominance: $t=-0.784, p=0.433$; attitudinal loyalty: $t=-1.753$, $p=0.081$; behavioural loyalty: $t=-1.026, p=0.306$ ) indicated that there is no significant difference between groups for all variables.

$53.3 \%$ of respondents were males and $46.7 \%$ were females. The highest education level of the majority was Advanced Level (48\%) while there were 92 respondents with a diploma and 48 with a first degree. Most of the respondents (34.3\%) represented the income category 45,00170,000 Sri Lankan rupees. It was evident that the most preferred smartphone brand among respondents is Samsung (40.3\%). While $27 \%$ of respondents preferred the Huawei brand, Apple held the third position with $15 \%$ usage.

\section{Results}

Structural Equation Modelling (SEM) procedure (Hair et al., 2010) was chosen for data analysis as SEM is one of the major analytical methods that has been widely applied in management and marketing research (Baumgartner and Homburg, 1996). Specifically, the covariance-based SEM (CBSEM) approach was chosen due to the parameter consistency and accuracy of the CBSEM approach when the sample size exceeds 250 observations (Reinartz et al., 2009). Outputs were produced using AMOS 23 package.

\subsection{Measurement model}

The measurement model was developed and the model fit was assessed using following criteria specified by Hair et al. (2010): CIMIN and degrees of freedom $\left(\chi^{2} / \mathrm{df}<3\right)$, Comparative Fit Index $(\mathrm{CFI}>0.90)$, Tucker-Lewis Index $(\mathrm{TLI}>0.90)$ Goodness of Fit Index $(\mathrm{GFI}>0.90)$, 
Root Mean Square Error of Approximation (RMSEA < 0.08), and Normed Fit Index (NFI > $0.90)$.

Initial measurement model showed a poor fit; therefore, modifications were made by drawing covariances among error terms. The modified measurement model showed a satisfactory model fit $\left(\chi^{2}=250.231, \mathrm{df}=93, \chi^{2} / \mathrm{df}=2.691 ; \mathrm{p}<0.001 ;[\mathrm{CFI}]=0.960 ;[\mathrm{TLI}]=0.948 ;[\mathrm{GFI}]=0.906\right.$; $[$ RMSEA $]=0.075 ;[\mathrm{NFI}]=0.938)$. All items loaded well (factor loadings greater than 0.6$)$ on respective factors and were statistically significant $(p<0.01)$. Cronbach's alpha $(\alpha>0.7)$ showed a satisfactory internal consistency (pleasure, $\alpha=0.939$; arousal, $\alpha=0.928$; dominance, $\alpha=0.830$; attitudinal loyalty, $\alpha=0.806$; behavioural loyalty, $\alpha=0.809)$. Convergent validity was assessed using composite reliability (CR) and average variance extracted (AVE) (Malhotra and Dash, 2016). CR values ( $>0.7)$ and AVE values $(>0.5)$ ensured satisfactory convergent validity. As suggested by Fornell and Larcker (1981), square roots of respective AVEs were compared with correlation coefficients to assess discriminant validity (see Table 1). With such satisfactory conditions, structural model was developed to test hypotheses.

Table 1: Convergent and discriminant validity

\begin{tabular}{lllllll}
\hline & AVE & $\mathbf{( 1 )}$ & $\mathbf{( 2 )}$ & $\mathbf{( 3 )}$ & $\mathbf{( 4 )}$ & (5) \\
\hline \hline (1) Brand Loyalty & .58 &. $\mathbf{7 6}$ & & & & \\
(2) Pleasure & .83 & .61 & .91 & & & \\
(3) Arousal & .76 & .76 & .66 & .87 & & \\
(4) Dominance & .59 & .75 & .58 & .61 & .77 & \\
(5) Attitudinal Loyalty & .60 & .72 & .59 & .76 & .75 & .77 \\
\hline \hline
\end{tabular}

Note: Square roots of respective AVEs are shown in the diagonal.

\subsection{Structural model and hypotheses testing}

As per model statistics, the structural model showed a satisfactory model fit $\left(\chi^{2}=264.741\right.$, df $=93, \chi^{2} / \mathrm{df}=2.847 ; \mathrm{p}<0.001 ;[\mathrm{CFI}]=0.956 ;[\mathrm{TLI}]=0.944 ;[\mathrm{GFI}]=0.904 ;[\mathrm{RMSEA}]=0.079$; $[\mathrm{NFI}]=0.935)$. Structural model testing results are shown in Figure 1 and the summary of hypotheses testing is given in Table 2 . 
Figure 1: Structural model testing results

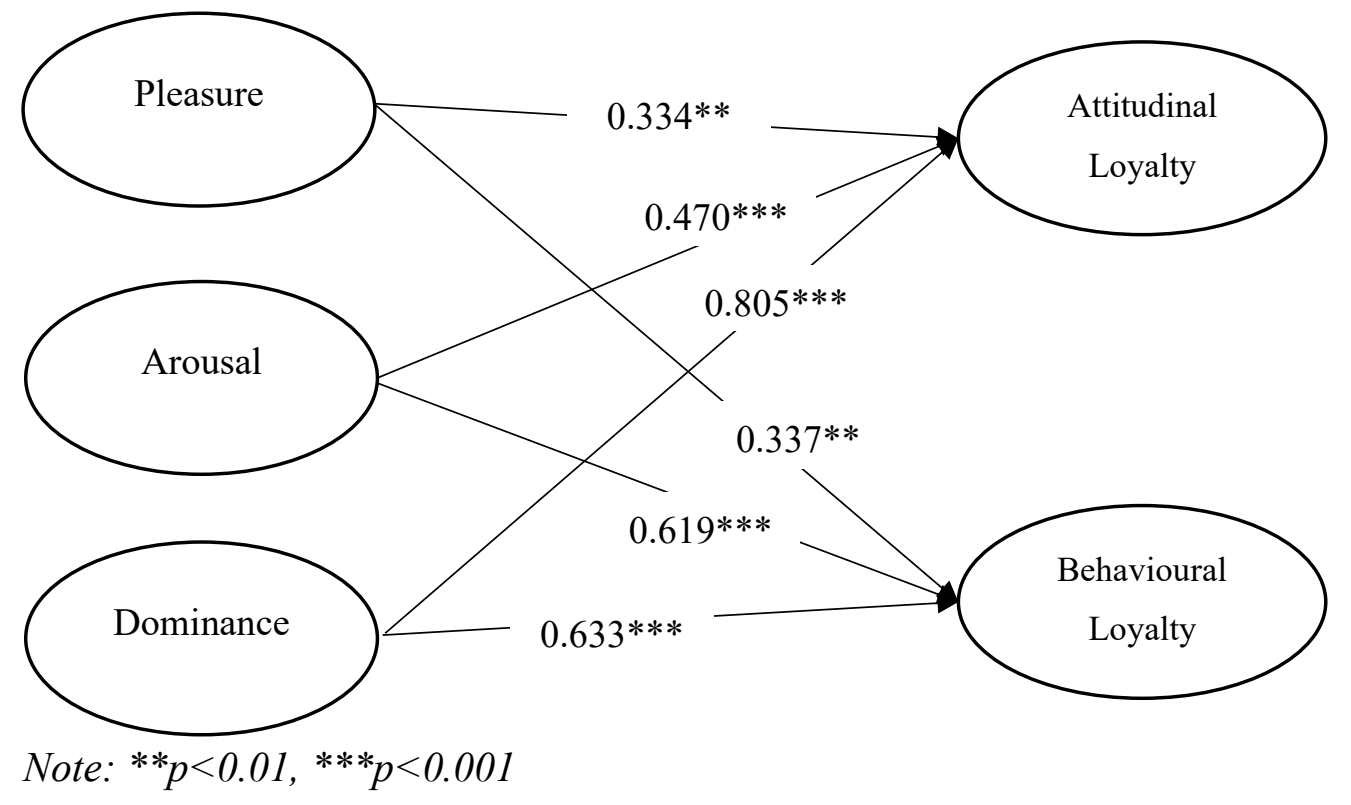

Table 2: Summary of hypotheses testing

\begin{tabular}{lllccccc}
\hline & $\begin{array}{l}\text { Independent } \\
\text { Variable }\end{array}$ & Dependant & $\boldsymbol{\beta}$ & S.E. & C.R. & $\boldsymbol{p}$ & Result \\
& & & & & & \\
\hline \hline H1a & Pleasure & Attitudinal Loyalty & .33 & .07 & 3.28 & .001 & Supported \\
H1b & Pleasure & Behavioural Loyalty & .33 & .10 & 3.16 & .002 & Supported \\
H2a & Arousal & Attitudinal Loyalty & .47 & .09 & 3.52 & .000 & Supported \\
H2b & Arousal & Behavioural Loyalty & .61 & .13 & 4.54 & .000 & Supported \\
H3a & Dominance & Attitudinal Loyalty & .80 & .09 & 7.21 & .000 & Supported \\
H3b & Dominance & Behavioural Loyalty & .63 & .11 & 7.09 & .000 & Supported \\
\hline \hline
\end{tabular}

As shown in Table 2, all hypotheses were empirically supported. Accordingly, pleasure found to have a positive effect on attitudinal loyalty $(\beta=0.334, p<0.01)$ and behavioural loyalty $(\beta$ $=0.337, p<0.01)$. Similarly, arousal positively affects attitudinal $(\beta=0.470, p<0.001)$ and behavioural loyalty $(\beta=0.619, p<0.001)$. Dominance found have the salient impact on both attitudinal $(\beta=0.805, p<0.001)$ and behavioural loyalty $(\beta=0.633, p<0.001)$. 


\subsection{Effect of gender}

To examine if the relationship between brand romance and brand loyalty differs from males to females, a multi-group analysis was performed. A Chi-square difference test was performed to compare models and it revealed that the difference between two models is statistically significant $\left(\chi^{2}\right.$ difference $\left.=42.311, p=0.001\right)$.

Table 3: Summary of multi-group analysis

\begin{tabular}{|c|c|c|c|c|c|c|}
\hline \multirow[b]{2}{*}{$\begin{array}{l}\text { Independent } \\
\text { Variable }\end{array}$} & \multirow[b]{2}{*}{$\begin{array}{l}\text { Dependant } \\
\text { Variable }\end{array}$} & \multicolumn{2}{|c|}{$\begin{array}{c}\text { Model } 1 \\
\text { Males } \\
(n=160)\end{array}$} & \multicolumn{2}{|c|}{$\begin{array}{l}\text { Model } 2 \\
\text { Females } \\
(n=140)\end{array}$} & \multirow{2}{*}{$\begin{array}{c}\text { Path } \\
\text { coefficient } \\
\text { difference } \\
p\end{array}$} \\
\hline & & $\beta 1$ & $p$ & $\beta 2$ & $p$ & \\
\hline Pleasure & Attitudinal Loyalty & .37 & $.016^{*}$ & .41 & $.031 *$ & $.035 *$ \\
\hline Pleasure & Behavioural Loyalty & .30 & $.029 *$ & .53 & $.025 *$ & $.031 *$ \\
\hline Arousal & Attitudinal Loyalty & .39 & $.000 * * *$ & .74 & $.004 * *$ & $.006 * *$ \\
\hline Arousal & Behavioural Loyalty & .49 & $.013 *$ & .98 & $.002 * *$ & $.009 * *$ \\
\hline Dominance & Attitudinal Loyalty & .88 & $.038 *$ & .62 & $.000 * * *$ & $.008 * *$ \\
\hline Dominance & Behavioural Loyalty & .72 & $.009 * *$ & .44 & $.011 * *$ & $.014 *$ \\
\hline
\end{tabular}

As shown in Table 3, the multi-group analysis revealed that the relationship between brand romance and brand loyalty differs from males to females, hence, $\mathrm{H} 4$ is supported. Pleasure and arousal have a cogent effect on brand loyalty among female Gen Y consumers. In contrast, dominance has the strongest effect on brand loyalty among men.

\section{Discussion and implications}

\subsection{Discussion of findings}

Findings broadly revealed that brand romance has a positive impact on Gen Y smartphone users' brand loyalty, hence, all hypotheses were supported. Pleasure had the least effect on brand loyalty which may be an indication that pleasing consumer is important, however, further actions are needed to maximize brand loyalty. Arousal had a greater impact on behavioral loyalty than on attitudinal loyalty denoting that arousal, as an emotional state, could drive repurchases of a brand. Moreover, findings revealed that dominance has a cogent effect on brand loyalty. This could be an indication that a consumer would strongly be committed to a brand, 
both attitudinally and behaviourally, once the brand dominates the consumer's cognition as a part of life.

These findings are consistent with previous scholarly works. At the broader level, this study confirms that emotional brand attachment is a significant predictor of brand loyalty (Loureiro et al., 2012; Phau et al., 2013; Thakur and Kaur, 2016). Hence, driving strategies to establish a consumer-brand emotional bond would result in more favorable attitudes about the brand and a long-term behavioral commitment. Specifically, from the brand romance perspective, the findings of this study are in line with prior scholarly works of Quester and Lim (2003) and Hanzaee et al. (2011) who found pleasure to be a significant predictor of brand loyalty. Further, the finding that arousal has a positive effect on brand loyalty, is consistent with the findings of Petzer et al. (2014). More importantly, this study re-confirms Mehrabian's (1996) reading of dominance as a strong emotional state. The finding that dominance is the salient predictor of brand loyalty is on par with Hatice and Cemal (2017) and Petzer et al. (2014).

An additional finding of this study was the gender difference in the relationship between brand romance and brand loyalty. The effect of pleasure and arousal on brand loyalty is comparatively higher among Gen Y females. This finding is consistent with Kuss and Griffiths (2011), Hew et al. (2017), and Qi et al. (2015) who found females to be more pleasure-seeking and tend to be aroused with smartphone brands. Dominance, in contrast, has a strong impact on brand loyalty among Gen Y males than females. This is, yet, consistent with Yeh et al. (2016), who emphasized that males are more independent and Hew et al. (2017) who found men to be strongly attached to smartphones. This denotes that, once a brand dominates the cognition of males, their independent nature would foster a much deeper commitment towards the brand, making it a "part of them".

This study makes both theoretical and empirical contributions. First, this study empirically validates extant knowledge on emotional brand attachment and brand loyalty in the smartphone industry. Second, this study took brand romance perspective to capture the emotional brand attachment and made a theoretical contribution by taking the multi-faceted nature of emotional brand attachment into account whereas most recent studies have treated brand attachment as a unidimensional construct. Third, a significant contribution is made by theorizing the effect of pleasure, arousal, and dominance on both attitudinal and behavioral brand loyalty. Fourth, this study could be the first attempt to extend the understanding of brand romance and brand loyalty with a view of gender difference. Finally, this study provides empirical evidence about brand 
romance and smartphone brand loyalty among Gen Y consumers, who are considered to be the heaviest users of emerging devices.

\subsection{Practical implications}

The findings of this study shed light on various implications for practitioners. Predominantly, this study signifies the need to consider the attainment of both attitudinal and behavioral loyalty. Fostering favorable attitudes towards the brand and ensuring a long-term behavioral commitment from consumers would be a focal point of branding strategy. This study informs smartphone manufacturers/marketers of the significance of contemplating both these aspects of brand loyalty in developing branding strategies. The findings broadly advise that wellfocused marketing and communication effort should be put in place to convert the consumerbrand relationship into an emotional attachment. Specifically, the marketing effort of smartphone brands should be directed towards brand loyalty through pleasing customers, arousing their cognition, and making the brand dominate their cognitive world. In doing so, various aspects of the marketing process should be fine-tuned well to maximize the brand's hedonic and functional benefits.

As said previously, Gen Y consumers are novelty seekers. Therefore, smartphone brands should focus on pleasing customers through innovations and novel features. Attractive designs, advanced features, improved performance, and durability would be key determinants of Gen Y smartphone users' pleasure and arousal. Especially, pleasure and arousal are central to the brand loyalty of Gen Y females, therefore, marketers can specifically design smartphone versions with customized designs/features that can please and arouse them. Dominance, being the salient predictor of brand loyalty among Gen Y users, demands considerable attention from marketers. It is worthy to note that dominance is the deepest level of emotional attachment, thus, need to make sure that customers will never be disappointed with the overall brand experience. The focus of every marketing effort must be a better product-use experience so that customers would consider the brand as a "part of them".

The findings further suggest that emotional attachment should be the center of brand positioning strategy, supported by well-crafted advertising/communication strategies. For example, emotional or transformational (imagery-portrayal) appeal could be effectively used as an executional framework of the advertising strategy, making the brand emotionally closer to consumers. Further, the brand positioning strategy can be aligned with Gen Y users' self and social identity profiles, helping the brand to dominate their minds. 


\subsection{Limitations and directions for future research}

This study, despite the empirical and theoretical significance, has some limitations. First, the study was limited to Sri Lanka and the sample was not randomly selected. Replications of this study in different socio-cultural contexts and cross-cultural investigations would be a promising research direction. Second, this study used a cross-sectional survey. A longitudinal study could capture the variation of emotional brand attachment and its effect on brand loyalty. This research was limited to Generation Y, thus, future investigations can validate these findings in other generational cohorts. Next, in addition to brand romance, there are other theoretical perspectives of emotional attachment (i.e., self-congruence, self/social identity) that future studies can embrace. Finally, in addition to gender, future studies may consider other possible moderators (i.e., hedonic and utilitarian product benefits, self-image).

\section{Conclusion}

This study investigated the effect of brand romance on smartphone brand loyalty of Generation Y consumers. A cross-sectional survey was conducted using a sample of 300 smartphone users. The results revealed that brand romance has a positive impact on brand loyalty and this association differs across gender. Based on the findings, numerous theoretical and empirical contributions were made along with practical implications. 


\section{References}

Aaker, D. A. (2009), Managing Brand Equity, Simon and Schuster, New York, NY.

Ali, W., Qadir, I., Khuhro, R. and Qureshi, Q. (2017), "Determinants of Brand Loyalty among Late Movers of Motorbike Industry in District Haripur, Pakistan: A Brand Romance Perspective", University of Haripur Journal of Management (UOHJM), Vol. 2 No. 1, pp. 133-144.

Aljomaa, S. S., Al.Qudah, M. F., Albursan, I. S., Bakhiet, S. F. and Abduljabbar, A. S. (2016), "Smartphone addiction among university students in the light of some variables", Computers in Human Behavior, Vol. 61, pp. 155-164.

Aron, A., Norman, C. C. and Aron, E. N. (1998), "The self-expansion model and motivation", Representative Research in Social Psychology, Vol. 22, pp. 1-13.

Bahri-Ammari, N., Van Niekerk, M., Ben Khelil, H. and Chtioui, J. (2016), "The effects of brand attachment on behavioral loyalty in the luxury restaurant sector", International Journal of Contemporary Hospitality Management, Vol. 28 No. 3, pp. 559-585.

Bakker, I., Van der Voordt, T., Vink, P. and de Boon, J. (2014), "Pleasure, arousal, dominance: Mehrabian and Russell revisited", Current Psychology, Vol. 33 No. 3, pp. 405-421.

Ballantyne, R., Warren, A. and Nobbs, K. (2006), "The evolution of brand choice", Journal of Brand Management, Vol. 13 No. 4, pp. 339-352.

Bandyopadhyay, S. and Martell, M. (2007), "Does attitudinal loyalty influence behavioral loyalty? A theoretical and empirical study", Journal of Retailing and Consumer Services, Vol. 14 No. 1, pp. 35-44.

Baumgartner, H. and Homburg, C. (1996), "Applications of structural equation modeling in marketing and consumer research: A review", International Journal of Research in Marketing, Vol. 13 No. 2, pp. 139-161.

Belk, R. W. (1988), "Possessions and the Extended Self", Journal of Consumer Research, Vol. 15 No. 2, pp. 139-168.

Blattberg, R. C. and Sen, S. K. (1974), "Market Segmentation Using Models of Multidimensional Purchasing Behavior: A new segmentation strategy designed to provide better information to the marketing decision maker", Journal of Marketing, Vol. 38 No. 4, pp. 17-28.

Boateng, H., Kosiba, J.P., Adam, D.R., Ofori, K.S. and Okoe, A.F. (2020), "Examining brand loyalty from an attachment theory perspective", Marketing Intelligence \& Planning, Vol. 38 No. 4, pp. 479-494. 
Bowlby, J. (1979), The Making and Breaking of Affectional Bonds, Tavistock Publications, London.

Chaudhuri, A. and Holbrook, M. B. (2001), "The Chain of Effects from Brand Trust and Brand Affect to Brand Performance: The Role of Brand Loyalty", Journal of Marketing, Vol. 65 No. 2, pp. 81-93.

Chen, Y. S., Tso-Jen, C. and Lin, C. C. (2016), "The analyses of purchasing decisions and brand loyalty for Smartphone consumers", Open Journal of Social Sciences, Vol. 4 No. 7, pp. 108-116.

Chen, C., Zhang, K. Z. K., Gong, X., Zhao, S. J., Lee, M. K. O. and Liang, L. (2017), "Examining the effects of motives and gender differences on smartphone addiction", Computers in Human Behavior, Vol. 75, pp. 891-902.

Dawn, B. V. and Thomas, L. P. (2013), "Generation Y values and lifestyle segments", Journal of Consumer Marketing, Vol. 30 No. 7, pp. 597-606.

Derks, D., Bakker, A. B., Peters, P. and van Wingerden, P. (2016), "Work-related smartphone use, work-family conflict and family role performance: The role of segmentation preference", Human Relations, Vol. 69 No. 5, pp. 1045-1068.

Dick, A. S. and Basu, K. (1994), "Consumer loyalty: towards an integrated conceptual approach", Journal of the Academy of Marketing Science, Vol. 22 No. 2, pp. 99-113.

Ehrenberg, A. S. C., Goodhardt, G. J. and Barwise, T. P. (1990), "Double Jeopardy Revisited", Journal of Marketing, Vol. 54 No. 3, pp. 82-91.

Esch, F. R., Langner, T., Schmitt, B. H. and Geus, P. (2006), "Are brands forever? How brand knowledge and relationships affect current and future purchases", Journal of Product \& Brand Management, Vol. 15 No. 2, pp. 98-105.

Feldman, L. A. (1995), "Valence focus and arousal focus: Individual differences in the structure of affective experience", Journal of Personality and Social Psychology, Vol. 69 No. 1, p. 153.

Floh, A., Zauner, A., Koller, M. and Rusch, T. (2014), "Customer segmentation using unobserved heterogeneity in the perceived-value-loyalty-intentions link", Journal of Business Research, Vol. 67 No. 5, pp. 974-982.

Fornell, C. and Larcker, D. F. (1981), "Evaluating Structural Equation Models with Unobservable Variables and Measurement Error", Journal of Marketing Research, Vol. 18 No. 1, pp. 39-50. 
Frasquet, M., Descals, A. M. and Ruiz-Molina, M. E. (2017), "Understanding loyalty in multichannel retailing: the role of brand trust and brand attachment", International Journal of Retail \& Distribution Management, Vol. 45 No. 6, pp. 608-625.

Gecti, F. and Zengin, H. (2013), "The relationship between brand trust, brand affect, attitudinal loyalty and behavioral loyalty: A field study towards sports shoe consumers in Turkey", International Journal of Marketing Studies, Vol. 5 No. 2, pp. 111-119.

Giovanis, A. and Athanasopoulou, P. (2017), "Gen Y-ers' brand loyalty drivers in emerging devices", Marketing Intelligence \& Planning, Vol. 35 No. 6, pp. 805-821.

Hair, J. F., Anderson, R. E., Babin, B. J. and Black, W. C. (2010), Multivariate data analysis, Upper Saddle River, NJ: Pearson.

Han, H., Nguyen, H. N., Song, H., Chua, B.-L., Lee, S. and Kim, W. (2018), "Drivers of brand loyalty in the chain coffee shop industry", International Journal of Hospitality Management, Vol. 72, pp. 86-97.

Hanzaee, K. H., Khoshpanjeh, M. and Rahnama, A. (2011), "Evaluation of the effects of product involvement facets on brand loyalty", African Journal of Business Management, Vol. 5 No. 16, pp. 6964-6971.

Hatice, A. and Cemal, Z. (2017), "What Type Relationship Do We Have with Our Brands? Is The Name of This Relationship Brand Romance?", International review of management and marketing, Vol. 7 No. 2, pp. 272-283.

Hew, J. J., Badaruddin, M. N. B. A. and Moorthy, M. K. (2017), "Crafting a smartphone repurchase decision making process: Do brand attachment and gender matter?", Telematics and Informatics, Vol. 34 No. 4, pp. 34-56.

Hung, W. H., Tseng, C. L., Ho, C. F. and Wu, C. C. (2018), "How social impact affects smartphone brand loyalty", Journal of Computer Information Systems, pp. 1-11.

Kahn, B. E., Kalwani, M. U. and Morrison, D. G. (1986), "Measuring Variety-Seeking and Reinforcement Behaviors Using Panel Data", Journal of Marketing Research, Vol. 23 No. 2, pp. 89-100.

Lee, K.C., Kang, I., Shin, M.M. and Park, C. (2013), "Internet addiction as a manageable resource: a focus on social network services", Online Information Review, Vol. 37 No. 1, pp. 28-41.

Khan, I. and Rahman, Z. (2017), "Brand experience and emotional attachment in services: The moderating role of gender", Service Science, Vol. 9 No. 1, pp. 50-61.

Kim, J. and Hahn, K. H. Y. (2012), "Effects of Personal Traits on Generation Y Consumers' Attitudes Toward the Use of Mobile Devices for Communication and Commerce", 
Human Technology: An interdisciplinary journal on humans in ICT environments, Vol. 8 No. 2, pp. 133-156.

Kim, J., Lee, H. and Lee, J. (2020), "Smartphone preferences and brand loyalty: A discrete choice model reflecting the reference point and peer effect", Journal of Retailing Consumer Services, Vol. 52, p. 101907.

Kim, M., Wong, S., Chang, Y. and Park, J. (2016), "Determinants of customer loyalty in the Korean smartphone market: Moderating effects of usage characteristics", Telematics and Informatics, Vol. 33 No. 4, pp. 936-949.

Kumar, J. and Nayak J. K. (2019), "Consumer psychological motivations to customer brand engagement: a case of brand community", Journal of Consumer Marketing, Vol. 36 No. 1, pp. 168-177.

Kuss, D. J. and Griffiths, M. D. (2011), "Online social networking and addiction-a review of the psychological literature", International journal of environmental research and public health, Vol. 8 No. 9, pp. 3528-3552.

Lazarevic, V. (2012), "Encouraging brand loyalty in fickle generation Y consumers", Young Consumers, Vol. 13 No. 1, pp. 45-61.

Levy, S. and Hino, H. (2016), "Emotional brand attachment: a factor in customer-bank relationships", International Journal of Bank Marketing, Vol. 34 No. 2, pp. 136-150.

Long-Tolbert, S. J. and Gammoh B. S. (2012), "In good and bad times: the interpersonal nature of brand love in service relationships", Journal of Services Marketing, Vol. 26 No. 6, pp. 391-402.

Loureiro, S. M. C., Ruediger, K. H. and Demetris, V. (2012), "Brand emotional connection and loyalty", Journal of Brand Management, Vol. 20 No. 1, pp. 13-27.

Loureiro, S. M. C., Sarmento, E. M. and Le Bellego, G. (2017), "The effect of corporate brand reputation on brand attachment and brand loyalty: Automobile sector", Cogent Business \& Management, Vol. 4 No. 1, p. 1360031.

Malhotra, N. K. and Dash, S. (2016), Marketing research: An applied orientation, Pearson.

Martins, J., Costa, C., Oliveira, T., Gonçalves, R. and Branco, F. (2019), "How smartphone advertising influences consumers' purchase intention", Journal of Business Research, Vol. 94, pp. 378-387.

McCarty, D. and Kaye, M. (1984), "Reasons for drinking: Motivational patterns and alcohol use among college students", Addictive Behaviors, Vol. 9 No. 2, pp. 185-188. 
Mehrabian, A. (1996), "Pleasure-arousal-dominance: A general framework for describing and measuring individual differences in Temperament", Current Psychology, Vol. 14 No. 4, pp. 261-292.

Mehrabian, A. and Russell, J. A. (1974), An approach to environmental psychology, The MIT Press.

Mukherjee, K. (2019), "Social media marketing and customers' passion for brands", Marketing intelligence \& planning, Vol. 38 No. 4, pp. 509-522.

Oliver, R. L. (1999), "Whence Consumer Loyalty?", Journal of Marketing, Vol. 63 No. 4_suppl1, pp. 33-44.

Park, C. W., MacInnis, D. J. and Priester, J. (2009), "Research directions on strong brand relationships", in MacInnis, D. J., Park, C. W. and Priester, J. R. (Eds.) Handbook of Brand Relationships, Routledge, pp. 379-393.

Park, C. W., Macinnis, D. J., Priester, J., Eisingerich, A. B. and Iacobucci, D. (2010), "Brand Attachment and Brand Attitude Strength: Conceptual and Empirical Differentiation of Two Critical Brand Equity Drivers", Journal of Marketing, Vol. 74 No. 6, pp. 1-17.

Patwardhan, H. and Balasubramanian, S. K. (2011), "Brand romance: a complementary approach to explain emotional attachment toward brands", Journal of Product \& Brand Management, Vol. 20 No. 4, pp. 297-308.

Petzer, D., Mostert, P., Kruger, L.-M. and Kuhn, S. (2014), "The dimensions of brand romance as predictors of brand loyalty among cell phone users", South African Journal of Economic and Management Sciences, Vol. 17 No. 4, pp. 457-470.

Phau, I., Teah, M., So, J.T., Parsons, A.G. and Yap, S.F. (2013), "Corporate branding, emotional attachment and brand loyalty: the case of luxury fashion branding", Journal of Fashion Marketing and Management: An International Journal, Vol. 17 No. 4, pp. 403-423.

Podsakoff, P. M., MacKenzie, S. B. and Podsakoff, N. P. (2011), "Sources of Method Bias in Social Science Research and Recommendations on How to Control It", Annual Review of Psychology, Vol. 63 No. 1, pp. 539-569.

Prasad, S., Garg, A. and Prasad, S. (2019), "Purchase decision of generation Y in an online environment", Marketing Intelligence \& Planning, Vol. 37 No. 4, pp. 372-385.

Qi, J. Y., Qu, Q. X., Zhou, Y. P. and Li, L. (2015), "The impact of users' characteristics on customer lifetime value raising: evidence from mobile data service in China", Information Technology and Management, Vol. 16 No. 4, pp. 273-290. 
Quester, P. and Lim, A. L. (2003), "Product involvement/brand loyalty: is there a link?", Journal of Product \& Brand Management, Vol. 12 No. 1, pp. 22-38.

Reimann, M. and Aron, A. (2009), "Self-expansion motivation and inclusion of brands in self", in MacInnis, D. J., Park, C. W. and Priester, J. R. (Eds.) Handbook of Brand Relationships, M.E. Sharpe, Armonk, NY and London, pp. 65-81.

Reinartz, W., Haenlein, M. and Henseler, J. (2009), "An empirical comparison of the efficacy of covariance-based and variance-based SEM", International Journal of Research in Marketing, Vol. 26 No. 4, pp. 332-344.

Round, D. J. G. and Roper, S. (2012), "Exploring consumer brand name equity: Gaining insight through the investigation of response to name change", European Journal of Marketing, Vol. 46 No. 7-8, pp. 938-951.

Shimp, T. A. (1988), "Consumer-Object Relations: A Conceptual Framework Based Analogously on Sternberg's Triangular Theory of Love", Advances in Consumer Research, Vol. 15 No. 1, pp. 163-169.

Smith, A. (2015), "U.S. Smartphone Use in 2015". Available at: https://www.pewresearch.org/internet/2015/04/01/us-smartphone-use-in-2015/ (Accessed: 10 July 2020).

Statcounter (2020), "Mobile Vendor Market Share Worldwide". Available at: https://gs.statcounter.com/vendor-market-share/mobile/worldwide (Accessed: 10 July 2020).

Statista (2020), "Smartphones - Statistics \& Facts". Available at: https://www.statista.com/topics/840/smartphones/ (Accessed: 06 July 2020).

Sun, Y., Lim, K. H., Jiang, C., Peng, J. Z. and Chen, X. (2010), "Do males and females think in the same way? An empirical investigation on the gender differences in Web advertising evaluation", Computers in Human Behavior, Vol. 26 No. 6, pp. 1614-1624.

Takao, M., Takahashi, S. and Kitamura, M. (2009), "Addictive Personality and Problematic Mobile Phone Use", CyberPsychology \& Behavior, Vol. 12 No. 5, pp. 501-507.

Tangsupwattana, W. and Liu, X. (2018), "Effect of emotional experience on symbolic consumption in Generation Y consumers", Marketing Intelligence \& Planning, Vol. 36 No. 5, pp. 514-527.

Thakur, A. and Kaur, R. (2016), "An Empirical Examination of Relationship Between Emotional Attachment and Attitudinal Brand Loyalty Towards Luxury Fashion Brands", DLSU Business Economics Review, Vol. 26 No. 1, pp. 70-80. 
Toufani, S., Stanton John, P. and Chikweche, T. (2017), "The importance of aesthetics on customers' intentions to purchase smartphones", Marketing Intelligence \& Planning, Vol. 35 No. 3, pp. 316-338.

Tsimonis, G. and Dimitriadis, S. (2014), "Brand strategies in social media", Marketing Intelligence \& Planning, Vol. 32 No. 3, pp. 328-344.

Ul Hassan, S. Q., Ilyas, M. and Rehman, C. A. (2016), "Corporate Branding, Emotional Attachment and Brand Loyalty: The Case of Luxury Fashion Branding", Kuwait Chapter of the Arabian Journal of Business Management Review, Vol. 6 No. 2, p. 43.

Wood, L. (2000), "Brands and brand equity: definition and management", Management Decision, Vol. 38 No. 9, pp. 662-669.

van Deursen, A. J. A. M., Bolle, C. L., Hegner, S. M. and Kommers, P. A. M. (2015), "Modeling habitual and addictive smartphone behavior: The role of smartphone usage types, emotional intelligence, social stress, self-regulation, age, and gender", Computers in Human Behavior, Vol. 45, pp. 411-420.

Yeh, C. H., Wang, Y. S. and Yieh, K. (2016), "Predicting smartphone brand loyalty: Consumer value and consumer-brand identification perspectives", International Journal of Information Management, Vol. 36 No. 3, pp. 245-257. 


\section{Appendix: Survey instrument}

\section{Pleasure}

P1: I love my smart phone brand

P2: Using this smart phone brand gives me a great pleasure

P3: I am really happy that this smart phone brand is available

\section{Arousal}

A1: I am attracted to this Smart Phone brand

A2: I desire my Smart Phone brand

A3: I want this Smart Phone brand

A4: I look forward to using this Smart Phone brand

\section{Dominance}

D1: My daydreams often include this smartphone brand

D2: This smartphone brand often dominates my thoughts

D3: Sometimes I feel I can't control my thoughts as they are obsessively on this smartphone brand

D4: This smartphone brand always seems to be on my mind

\section{Attitudinal Loyalty}

AL1: I will be without a smartphone rather than using another brand

AL2: I am committed to this smartphone brand

AL3: I am ready to pay a higher price for this smartphone brand

\section{Behavioural Loyalty}

PL1: I prefer only this smartphone brand

PL2: If this smartphone brand is not available, I will buy it in another time

PL3: I will buy the same smartphone brand in future 